$\mathrm{A} \int_{\text {ass }} \mathrm{H}$

Article history :

Received : 02.11.2015

Revised : 11.05.2016

Accepted : 19.05.2016

Members of the Research Forum

Associated Authors:

${ }^{1}$ ICAR-Indian Institute of Sugarcane Research, Dilkusha, LUCKNOW (U.P.) INDIA
Author for correspondence : DILIP KUMAR

ICAR-Indian Institute of Sugarcane Research, Dilkusha, LUCKNOW (U.P.) INDIA

Email : dilipiisr@gmail.com
THEASIAN JOURNALOF HORTICULTURE

Volume 11 | Issue 1 | June, 2016 | 189-193

Visit us -www.researchjournal.co.in

\title{
Effect of some Indian herbs and chemical on shelf life of sugarcane juice
}

\section{DILIP KUMAR AND PRIYANKA SINGH ${ }^{1}$}

ABSTRACT : The present study was carried out to provide hygienic, shelf-stable sugarcane juice to people and encourage the industrialists to start sugarcane juice production on commercial scale. Different lots of sugarcane juice were subjected to heat treatment at $75^{\circ} \mathrm{C}$ for 15 minutes $\left(\mathrm{T}_{1}\right)$. Heat treatment after addition of lemon juice + ginger + Pudina extracts + black salt $\left(\mathrm{T}_{2}\right)$, heat treatment after addition of lemon juice + ginger + Tulsi extracts + black salt $\left(\mathrm{T}_{3}\right)$, heat treatment after addition of 0.04 per cent propyl parabens $\left(\mathrm{T}_{4}\right)$ and heat treatment after addition of 0.06 per cent propyl parabens $\left(\mathrm{T}_{5}\right)$. Fresh sugarcane juice was taken as control $\left(\mathrm{T}_{0}\right)$. All the treated juices were bottled and were pasteurized in hot water at $75{ }^{\circ} \mathrm{C}$ for 15 minutes. All the lots were stored for 30 days at room temperature $\left(30 \pm 5^{\circ} \mathrm{C}\right)$. The prepared juice were observed for physico-chemical and microbiological aspects like T.S.S, pH, colour, total plate counts, yeast and mould growth along with sensory evaluation.The experiment was laid down using Completely Randomized Design.From the experiment it was clear that the overall performance of the above characteristics was found best when the juice was preserved by using heat treatment after addition of 0.04 per cent propyl parabens $\left(\mathrm{T}_{4}\right)$. However, the use of Pudina in the treatment $\mathrm{T}_{3}$ and Tulsi in the treatment $\mathrm{T}_{4}$ have shown the maximum values of sensory attributes upto the interval of 5 days as compared to others.

KEY WORDS : Sugarcane juice, Heat treatment, Storage, Sensory evaluation

HOW TO CITE THIS ARTICLE : Kumar, Dilip and Singh, Priyanka (2016). Effect of some Indian herbs and chemical on shelf-life of sugarcane juice. Asian J. Hort., 11(1) : 189-193, DOI : 10.15740/HAS/ TAJH/11.1/189-193. 